Ophthalmologica 1961;141:362

\title{
Resistenzbestimmung in der Ophthalmologie
}

G.

\section{Saubermann}

\section{Basel}

Erscheint später ausführlich in dieser Zeitschrift

Diskussion

H. J. Hegner (Luzern): Der Referent hat uns wiederum sehr eindrücklich vor dem unbedachten Gebrauch der Antibiotika gewarnt. In welchem Maß gilt diese Warming auch gegenüber ausschließlich lokal applizierbaren Antibiotika. wie Bacitracin und Neoniycin? 